\title{
Aerosols and nucleation in eastern China: first insights from the new SORPES-NJU station
}

\author{
E. Herrmann ${ }^{1,2, *}$, A. J. Ding ${ }^{1}$, V.-M. Kerminen ${ }^{2}$, T. Petäjä ${ }^{2}$, X. Q. Yang ${ }^{1}$, J. N. Sun ${ }^{1}$, X. M. Qi ${ }^{1}$, H. Manninen ${ }^{2}$, \\ J. Hakala ${ }^{2}$, T. Nieminen ${ }^{2}$, P. P. Aalto ${ }^{2}$, M. Kulmala ${ }^{2}$, and C. B. Fu ${ }^{1}$ \\ ${ }^{1}$ School of Atmospheric Sciences \& Institute for Climate and Global Change Research, Nanjing University, Nanjing, P. R., \\ China \\ ${ }^{2}$ Department of Physics, University of Helsinki, Helsinki, Finland \\ * now at: Laboratory of Atmospheric Chemistry, Paul Scherrer Institute, Villigen, Switzerland
}

Correspondence to: E. Herrmann (erik.herrmann@iki.fi)

Received: 5 July 2013 - Published in Atmos. Chem. Phys. Discuss.: 28 August 2013

Revised: 20 December 2013 - Accepted: 25 January 2014 - Published: 27 February 2014

\begin{abstract}
Aerosols and new particle formation were studied in the western part of the Yangtze River Delta (YRD) at the Station for Observing Regional Processes of the Earth System, Nanjing University (SORPES-NJU). Air ions in the diameter range $0.8-42 \mathrm{~nm}$ were measured using an air ion spectrometer, and a differential mobility particle sizer (DMPS) provided particle number size distributions between 6 and $800 \mathrm{~nm}$. Additionally, meteorological data, trace gas concentrations, and $\mathrm{PM}_{2.5}$ values were recorded. During the measurement period from 18 November 2011 to 31 March 2012 , the mean total particle concentration was found to be $23000 \mathrm{~cm}^{-3}$ and the mean $\mathrm{PM}_{2.5}$ value was $90 \mu \mathrm{g} \mathrm{m}^{-3}$, well above national limits. We observed 26 new particle formation events occurred during the measurement period, producing $6 \mathrm{~nm}$ particles at a rate of about $1 \mathrm{~cm}^{-3} \mathrm{~s}^{-1}$. Typical particle growth rates were between 6 and $7 \mathrm{~nm} \mathrm{~h}^{-1}$. On average, new particle formation and growth were estimated to enhance cloud condensation nuclei concentration by about a factor of two during these event days. Ion measurements showed the typical cluster band below $2 \mathrm{~nm}$, with total ion concentrations between about 600 and $1000 \mathrm{~cm}^{-3}$. A peculiar feature of the ion measurements were heightened ion cluster concentrations during the nights before the event days. At $2 \mathrm{~nm}$, the formation rate of charged particles was only about $0.2 \%$ of the total rate, pointing towards an only marginal role of ion-induced nucleation. Based on observations, a simple empirical criterion was deducted to estimate particle formation probability. Dominated by radiation and relative humidity, the criterion can predict the occurrence of particle formation
\end{abstract}

with a $90 \%$ accuracy. In a similar fashion, a reasonably accurate estimate of particle formation rates was derived. Combined, these parameters allow for a description of particle formation based on a few basic measured variables.

\section{Introduction}

Atmospheric aerosol particles play a significant role in Earth's radiative balance (Lohmann and Feichter, 2005; Bellouin et al., 2008; IPCC, 2013), in addition to which they have adverse health effects (e.g., Wichmann and Peters, 2000; Pope and Dockery, 2006). A central phenomenon related to atmospheric aerosols is the formation of new particles (nucleation) and their subsequent growth to larger sizes. This phenomenon has been observed almost all over the world under a wide variety of conditions (Kulmala et al., 2004; Kulmala and Kerminen, 2008). Model studies suggest that new atmospheric particle formation contributes significantly to the global cloud condensation nuclei $(\mathrm{CCN})$ budget and thereby to indirect climate forcing by atmospheric aerosols (Merikanto et al., 2009; Yu and Luo, 2009; Kazil et al., 2010; Makkonen et al., 2012).

As part of the general growing concern regarding environmental issues, aerosols and particle formation research efforts have increased in China during recent years. However, so far only a few comprehensive studies have been published (e.g., Wu et al., 2007; Shen et al., 2011). Instead, many projects have had a rather campaign character, presenting 
only a few weeks of observations. The published studies have concentrated on the Beijing area (e.g., Yue et al., 2011; Gao et al., 2012; Zhang et al., 2011), Pearl River Delta, including Hong Kong (e.g., Liu et al., 2008; Gong et al., 2010; Yao et al., 2010), and urban areas in general (e.g., Gao et al., 2007, 2011; Xu et al., 2011), but with few data on background sites (e.g., Guo et al., 2012). For example, the Yangtze River Delta (YRD) - a hotspot of human activity with its cumulative population of about 100 million people, the largest conglomerate of adjacent megacities in the world, and one of the motors of Chinese industrial development and - has seen only little research activity in terms of aerosols and their formation in the atmosphere (e.g., Huang et al., 2013). Most of the published research does not extend to sizes below $10 \mathrm{~nm}$ of the aerosol particle diameter (e.g., Du et al., 2012), and no data have been published on sizes down to that of freshly nucleated particles $(1-2 \mathrm{~nm})$.

The Station for Observing Regional Processes of the Earth System, Nanjing University (SORPES-NJU), has been set up outside the city of Nanjing to measure mainly background air masses at the western end of the Yangtze River Delta (YRD). The station is designated to evolve into a "flagship station", according to the proposition by Hari et al. (2009), and currently it houses a number of aerosol, trace gas and meteorological measurement instruments (Ding et al., 2013a, b). In this article, we present the first results from ongoing, continuous measurements of particle number size distributions performed at the SORPES-NJU site, the main focus being on atmospheric new particle formation. The measurement period spans from 18 November 2011 to 31 March 2012, forming the longest and most comprehensive data set on aerosols and related variables in that region to date.

Our main goal in this paper is to shed new light on the new particle formation process and subsequent particle growth in the background air of the YRD in China. Besides analyzing the general character of this phenomenon, we aim to address the following scientific questions: (1) how frequent is regional new particle formation at our site, and how is it affected by the presence of sulfuric acid and related factors? (2) Do ions play any role in the new particle formation process? (3) Does new particle formation influence regional cloud condensation nuclei concentrations? We will also investigate whether it is possible to make any predictions about the occurrence of new particle formation at our measurement site based on available knowledge about the factors influencing this process, and whether such predictions can be extended to the new particle formation rate.

\section{Measurement station}

\subsection{Site and location}

The measurement site, SORPES-NJU, is located about $20 \mathrm{~km}$ east of downtown Nanjing in eastern China. The exact co- ordinates are $32.12^{\circ} \mathrm{N}$ and $118.95^{\circ} \mathrm{E}$. Nanjing has a humid subtropical climate with high relative humidity during summer. Haze occurs frequently. In the summer, temperatures can be well above $30^{\circ} \mathrm{C}$, while temperatures somewhat below $0^{\circ} \mathrm{C}$ are not uncommon during the winter months. The station is situated on a hill rising about $40 \mathrm{~m}$ above its surroundings, overlooking the new campus of Nanjing University, which can be considered a suburban environment. With prevailing easterly winds throughout the year, the station mainly monitors YRD background air. The station currently measures aerosol particles, trace gases, fluxes, radiation and meteorological variables. A detailed account of the measurement station and its intents and purposes is presented in Ding et al. (2013a).

The site is located in a relatively rural environment with few local emission sources within $2-3 \mathrm{~km}$. There is a large petro-industrial zone located about 5-10 km northwest of the site, but because of prevailing winds from the east (Ding et al., 2013a) and some small hills between this zone and the site, these air masses are rarely transported to the site. Besides these circumstances, an important local source of PM worth mentioning is dust originating from nearby roads and intensive construction activities at the campus area and 2$5 \mathrm{~km}$ east of the station: transport of soil and stones often make the roads very dirty and this dust can easily be blown into the atmosphere by strong wind and vehicle-introduced turbulence, especially during the dry winter season. These activities have been observed to affect particulate matter concentrations at our site, especially in the coarse particle size range, but their exact contribution is very difficult to quantify. The influence of construction activities on submicron particle number concentrations is expected to be minor. The mainly regional sources are located in the east and southeast direction with a distance up to $300 \mathrm{~km}$, with many factories/power plants located along the Yangtze River, and more developed cities, such as Shanghai, Suzhou, Wuxi, Changzhou and Nanjing city clusters, located on the south side of the Yangtze River.

\subsection{Instrumentation and measurements}

The central aerosol instrumentation used in this study consists of an air ion spectrometer (AIS) and a differential mobility particle sizer (DMPS, built at Helsinki University). Similar instrumentation combinations have previously been successfully used in the study of atmospheric nucleation (e.g., Manninen et al., 2010).

The AIS consists of two parallel DMAs (differential mobility analyzer) for negative and positive air ions, respectively. The inner walls of the DMAs are outfitted with electrometers, allowing for a direct detection of the currents caused by ion impact on the wall. The AIS detects ions between 0.8 and $42 \mathrm{~nm}$ (mobility) diameter in 21 channels (size ranges) per DMA. During the measurements presented here, the AIS was operated in a 2 plus 1 min cycle ( 2 min sampling 


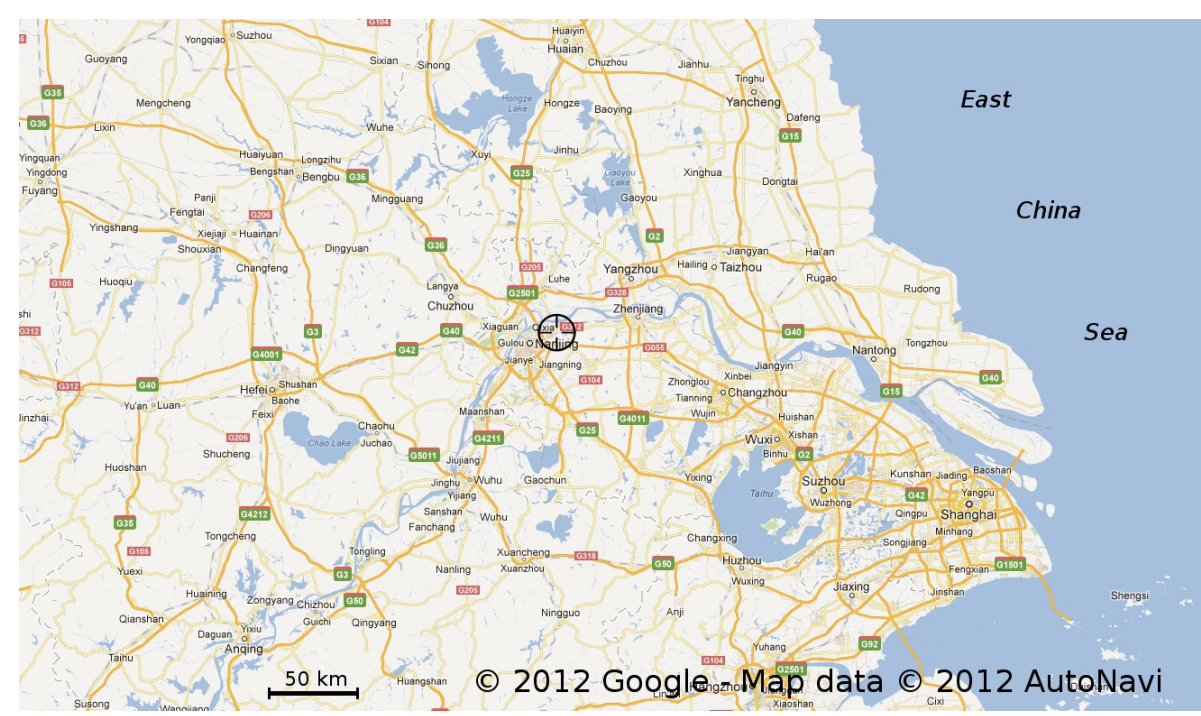

Fig. 1. Location of the SORPES-NJU measurement station within eastern China and the Yangtze River Delta (YRD).

plus 1 min background determination), making for a time resolution of $3 \mathrm{~min}$. To minimize data deterioration caused by the deposition of particles on the inner surfaces of the DMAs, both analyzers had to be cleaned thoroughly at least once per month. Deposition of dirt onto the nets inside the venturi flow tubes can lower the flow rate and thus effect the operation of the mobility analyzers. These nets were cleaned at least once per week. Data were verified visually and based on typical signatures; poor quality data were excluded on a full-day basis from further numerical analysis. The AIS is described in detail in Mirme et al. (2007).

The differential mobility particle sizer used in this study can be described as a "virtual twin" DMPS, i.e., a single DMPS run at two different flow rates to extend its size range (Salma et al., 2011). The inlet was equipped with an impactor of $2.5 \mu \mathrm{m}$ cutoff diameter to avoid the deposition of large particles inside the instrument. The sample was dried using Nafion tubes, and equilibrium charge was ensured by two americium-241 sources (each about $37 \mathrm{kBq}$ ). Particles are counted by a TSI 3772 butanol CPC (condensation particle counter). The DMPS provides the number size distribution between 6 and $800 \mathrm{~nm}$ mobility diameter. The time resolution is $10 \mathrm{~min}$.

Besides aerosol and air ion size distribution data, this study also uses the following data: $\mathrm{PM}_{2.5}$, global radiation, temperature, wind speed and direction, ozone concentration, and $\mathrm{SO}_{2}$ concentration. All instruments used are listed in Table 1 and more detailed descriptions of the instrumentations were given by Ding et al. (2013a).

\subsection{Data analysis}

The analysis of the particle size distribution data in general and particle formation events in particular follows the proce-
Table 1. Instruments used in this study.

\begin{tabular}{ll}
\hline Measurements & Instruments \\
\hline Aerosol particles 6-800 nm & DMPS (University of Helsinki) \\
Air ions 0.8-42 nm & AIS (Airel Ltd., Estonia) \\
$\mathrm{PM}_{2.5}$ & TEI SHARP-5030 \\
$\mathrm{O}_{3}$ & TEI 49i \\
$\mathrm{SO}_{2}$ & TEI 43i \\
Metrological parameters (Air & CAMPBELL CR3000-TD \\
temperature,global radiation, & \\
wind, relative humidity) & \\
\hline
\end{tabular}

dures described in great detail by Kulmala et al. (2012). The growth rate (GR) of a particle population can be expressed as

$\mathrm{GR}=\frac{\mathrm{d} d_{\mathrm{p}}}{\mathrm{d} t}=\frac{\Delta d \mathrm{p}}{\Delta t}=\frac{d_{\mathrm{p} 2}-d_{\mathrm{p} 1}}{t_{2}-t_{1}}$

as close to the measured formation $r$, where the diameters $d_{\mathrm{p} 1}$ and $d_{\mathrm{p} 2}$ describe the particle population at times $t_{1}$ and $t_{2}$, respectively. Within the framework of the Kulmala et al. (2012) protocol, the maximum concentration method was used, in which the center of the measured size bin is used as the representative diameter. The formation rate $J_{d_{\mathrm{p}}}$ of particles of diameter $d_{\mathrm{p}}$ is calculated as

$J_{d_{\mathrm{p}}}=\frac{\mathrm{d} N_{d_{\mathrm{p}}}}{\mathrm{d} t}+\operatorname{CoagS}_{d_{\mathrm{p}}} \cdot N_{d_{\mathrm{p}}}+\frac{\mathrm{GR}}{\Delta d_{\mathrm{p}}} \cdot N_{d_{\mathrm{p}}}+S_{\text {losses }}$

Here, Coag $S_{d_{\mathrm{p}}}$ is the coagulation sink for particles between $d_{\mathrm{p}}$ and $d_{\mathrm{p}}+\Delta d_{\mathrm{p}}$, GR is their respective growth rate, and $S_{\text {losses }}$ covers additional loss processes. For the treatment of ions, additional terms are necessary to include recombination and charging by smaller particles. The actual nucleation rate, 
i.e., the formation rate of critical clusters, can be deducted from the apparent formation rate using the condensation or coagulation sink and (an estimate of) the growth rate between the relevant sizes as parameters (Lehtinen et al., 2007). Also, values such as the concentration of available vapor or the vapor source rate can be extracted from size distribution data (see Kulmala et al. (2012) for further details).

Sulfuric acid has been identified as the main driver of atmospheric nucleation (Kerminen et al., 2010; Sipilä et al., 2010; Kulmala et al., 2013) and an important contributor to the growth of newly formed particles (Boy et al., 2005; Fiedler et al., 2005; Yue et al., 2010). Theoretically, gaseous sulfuric acid concentrations are expected to depend on sulfur dioxide concentration, radiation level and preexisting particle loading, more specifically condensation sink (Petäjä et al., 2009). The most comprehensive semi-empirical sulfuric acid proxy to date has been constructed by Mikkonen et al. (2011), who compared data collected at seven sites in Europe and North America. They have determined a proxy for each site as well as a universal proxy that is thought to be valid elsewhere as well. Their universal proxy has the form

$$
\begin{aligned}
{\left[\mathrm{H}_{2} \mathrm{SO}_{4}\right]_{\text {universal }}=} & 8.21 \times 10^{-3} \cdot k \cdot \text { Radiation } \\
& \cdot\left[\mathrm{SO}_{2}\right]^{0.62} \cdot(\mathrm{CS} \cdot \mathrm{RH})^{-0.13}
\end{aligned}
$$

where $k$ is the reaction rate constant and dependent on temperature. Radiation, $\left[\mathrm{SO}_{2}\right], \mathrm{CS}$, and $\mathrm{RH}$ are (global) radiation, $\mathrm{SO}_{2}$ concentration, condensational sink, and relative humidity, respectively. Among the sites considered by Mikkonen et al. (2011) is the city of Atlanta, Georgia (USA), which has similar climate conditions to Nanjing. Therefore we have also used the best Atlanta proxy to gain an estimate of sulfuric acid concentrations. The Atlanta proxy has the following form:

$$
\begin{aligned}
{\left[\mathrm{H}_{2} \mathrm{SO}_{4}\right]_{\text {Atlanta }}=} & 1.30 \times 10^{-1} \cdot k \cdot \text { Radiation }^{1.10} \\
& \cdot\left[\mathrm{SO}_{2}\right]^{0.69} \cdot \mathrm{CS}^{-0.53} \cdot \mathrm{RH}^{-1.92} .
\end{aligned}
$$

To gain more insight into the relation of incoming air masses and nucleation behavior, we used the Hybrid SingleParticle Lagrangian Integrated Trajectory (HYSPLIT) dispersion model (Draxler and Hess, 1998), following a method described by Ding et al. (2013c). For each day when nucleation was observed, the model was run 1-day backwardly with 3000 particles released $100 \mathrm{~m}$ over the measurement site. Thus, a footprint (with a layer of $100 \mathrm{~m}$ ) "retroplume" was identified, providing information about the origin and history of the observed air masses (more detail about the modeling method have been provided by Ding et al., 2013c).

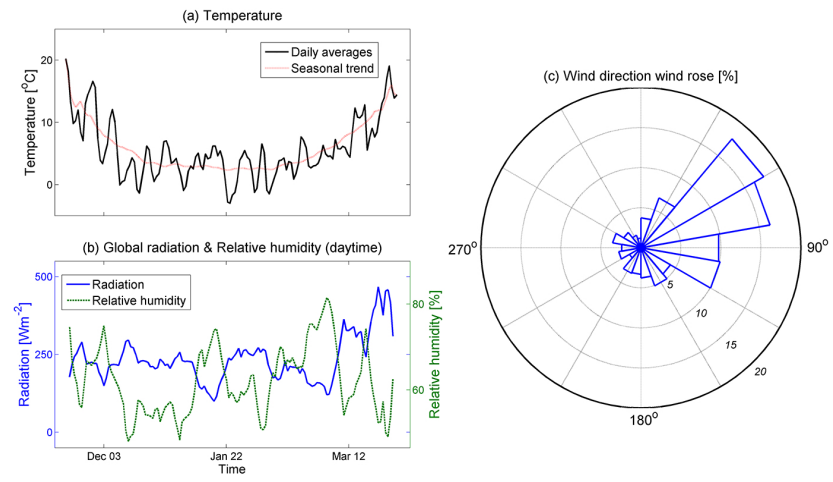

Fig. 2. Meteorological conditions during the measurement period 18 November-31 March. (a) Temperature with daily averages and seasonal trend. (b) Global radiation and relative humidity. (c) Wind direction wind rose.

\section{Results and discussion}

\subsection{Overview of the measurements}

\subsubsection{Meteorological conditions}

The data presented in this study covers the period from the middle of November 2011 to the end of March 2012, i.e., local winter, framed by late autumn and early spring. The average mean temperature during this period was $5.2^{\circ} \mathrm{C}$, with daily averages from -3.0 to $20.2^{\circ} \mathrm{C}$. The temperature profile (Fig. 2a) was characterized by quite a regular oscillating shape, indicating the passing of cold fronts. Throughout the measurement period, daily average temperatures oscillated by as much as $10^{\circ} \mathrm{C}$ within a few days. However, underlying this fluctuation, the seasonal trend was clearly visible.

The radiation (Fig. 2b) did not exhibit a clear seasonal behavior for most of the measurement period, as the change in the Sun's position would suggest. The significance of this observation will be discussed in the sections related to nucleation frequency and nucleation characteristics. However, the radiation data plot quite convincingly conveys its anticorrelation with the humidity data in the same panel: high humidity suggests rain or clouds, which again means less radiation at the ground level. The wind direction wind rose histogram (Fig. 2c) reflects the dominance of easterly winds, with the main wind direction being around $70^{\circ}$ and almost all wind directions between $30^{\circ}$ and $120^{\circ}$. This means that the station hardly ever sees pollution from downtown Nanjing in the west and the industrial zone in the northwest, whereas air masses from the YRD occur frequently. The impact of this on aerosol characteristics and new particle formation will be discussed in the appropriate sections. 

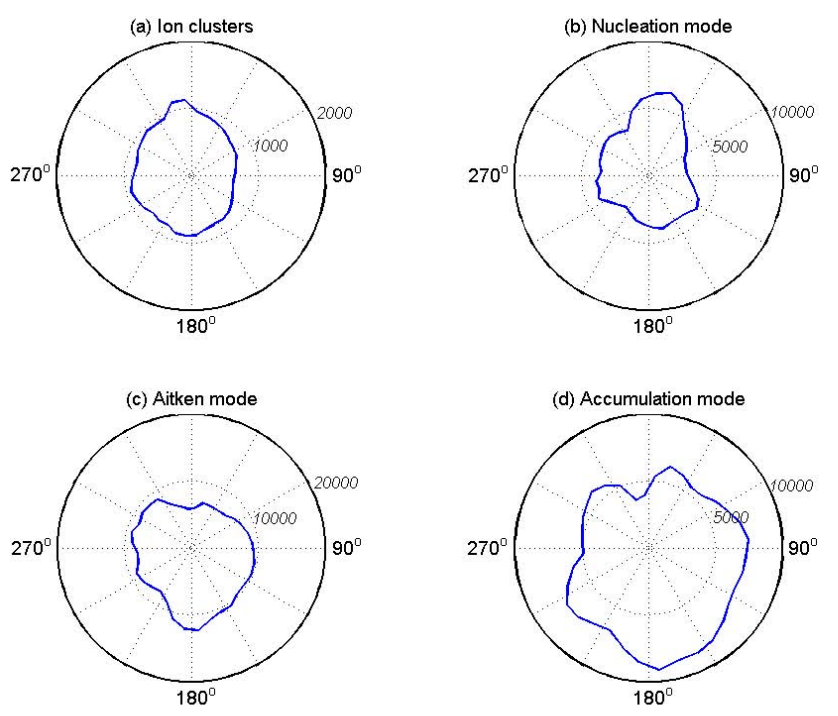

Fig. 3. Air ion and aerosol mode concentrations $\left(\right.$ all $\mathrm{cm}^{-3}$ ) as a function of wind direction. (a) Ion clusters $<2 \mathrm{~nm}$. (b) Nucleation mode 6-25 nm. (c) Aitken mode 25-90 nm. (d) Accumulation mode $90-800 \mathrm{~nm}$.

\subsubsection{Aerosol characteristics}

Figure 3 illustrates how air ion concentrations and modal aerosol particle concentrations depend on the wind direction. In Fig. 3a, the ion clusters represent the sum of positive and negative ions below $2 \mathrm{~nm}$ of mobility diameter (note: generally, in this manuscript, the unqualified "ion" will always mean total ions, i.e., the sum of positive and negative ions). The nucleation mode (Fig. 3b) covers the diameter range 6 to $25 \mathrm{~nm}$, the Aitken mode (Fig. 3c) the range 25 to $90 \mathrm{~nm}$, and the accumulation mode (Fig. 3d) the range 90 to $800 \mathrm{~nm}$.

Considering the ion clusters, the most interesting detail is the comparison to the accumulation mode in Fig. 3d. While the ion cluster concentration did not change much with the wind direction, it appeared to have some inverse relation with the accumulation mode particle number concentration: the accumulation mode particle number concentrations were the highest at the wind directions between $60^{\circ}$ and $180^{\circ}$, while ion cluster concentrations were the lowest for the same wind directions. There was also a local maximum in the ion cluster concentration between about $330^{\circ}$ and $360^{\circ}$ and a corresponding minimum in the accumulation mode particle number concentration. However, this latter feature should not be overstated as winds from that direction are rare (Fig. 2c) and statistics thus poor. In any case, the relationship between ion cluster and accumulation mode concentration can be easily enough explained with the coagulation sink due to accumulation mode particles, which remove small clusters and particles.

The nucleation mode (Fig. 3b) displayed two main features. Firstly, the average nucleation mode concentrations were relatively low in the prevailing wind direction (east- erly). Secondly, when the wind came from the north $\left(0-30^{\circ}\right)$, nucleation mode concentrations were almost twice as high as for the other wind directions. These observations can be interpreted as a higher nucleation probability for northern air masses and a lower nucleation probability for other wind directions. Comparing this to the Aitken and especially the accumulation mode (Fig. 3c and d), we observed rather low particle number concentrations in the Aitken and accumulation mode for the northern air masses. This suggests that the high nucleation mode concentrations (i.e., higher nucleation probability) in this sector can be explained at least partly as a consequence of lower concentrations of particles, attributing the dominant contribution to the condensation and coagulation sink. In accordance with this, relatively high concentrations of Aitken and accumulation mode particles were associated with easterly winds, explaining the lack of nucleation from this direction by the same mechanism.

During the measurement period from 18 November 2011 to 31 March 2012, on average (median), a total (sum of positive and negative ions) of $770 \mathrm{~cm}^{-3}$ ion clusters below $2 \mathrm{~nm}$ diameter were observed, with the 25 th and 75 th percentiles being $600 \mathrm{~cm}^{-3}$ and $970 \mathrm{~cm}^{-3}$, respectively. These observations are in line with earlier findings that the "cluster band" below $2 \mathrm{~nm}$ is almost always present and subject only to relatively small fluctuations (Hirsikko et al., 2005). Between 6 and $25 \mathrm{~nm}$, i.e., in what could be considered the nucleation mode, a median of $3500 \mathrm{~cm}^{-3}$ particles was observed, with 25 th and 75th percentiles of $2100 \mathrm{~cm}^{-3}$ and $6000 \mathrm{~cm}^{-3}$, respectively. For the Aitken mode $(25-90 \mathrm{~nm})$ and the accumulation mode $(90-800 \mathrm{~nm})$, the median $(25 \mathrm{th}$ and 75 th percentiles) were $8500 \mathrm{~cm}^{-3}\left(6100\right.$ and $\left.11500 \mathrm{~cm}^{-3}\right)$ and $6600 \mathrm{~cm}^{-3}$ (4700 and $9100 \mathrm{~cm}^{-3}$ ), respectively. To estimate the fraction of charged particles, we integrated ion and particle number concentrations in the instruments' overlapping region from 6 to $30 \mathrm{~nm}$. For the total particle to ion ratio, we found a median value of 4.4 (percentiles 3.4 and 5.9). Table 2 lists these numbers together with the mean, median, and 5th, 25th, 75th and 95th percentiles to characterize the aerosol population more completely. Considering modal particle number concentrations, the nucleation and Aitken mode showed the largest variations, accounting for days with and without new particle formation. The range of accumulation mode concentrations, on the other hand, was not related to local phenomena but rather an indication of the pollution level of the incoming air masses. Accordingly, the median and percentiles of $\mathrm{PM}_{2.5}$ mass concentrations $\left(79,47,116 \mu \mathrm{g} \mathrm{m}^{-3}\right.$ ) quite closely followed the respective percentiles of the accumulation mode particle number concentrations.

\subsection{Aerosol formation and growth}

\subsubsection{General characteristics}

All recorded new particle formation events were of type Ib.2, according to the classification by Hirsikko et al. (2007), with 
Table 2. Aerosol population statistics.

\begin{tabular}{lrrrrrr}
\hline & Mean & 5th percentile & 25th percentile & Median & 75th percentile & 95th percentile \\
\hline Total N $\left[\mathrm{cm}^{-3}\right]$ & 23300 & 9300 & 14600 & 20000 & 26400 & 38700 \\
Ion clusters $\left[\mathrm{cm}^{-3}\right]$ & 840 & 240 & 600 & 770 & 970 & 1450 \\
Nucl. mode $\left[\mathrm{cm}^{-3}\right]$ & 6700 & 960 & 2100 & 3500 & 6000 & 14300 \\
Aitken mode $\left[\mathrm{cm}^{-3}\right]$ & 9500 & 3700 & 6100 & 8500 & 11500 & 18700 \\
Accu. mode $\left[\mathrm{cm}^{-3}\right]$ & 7100 & 2500 & 4700 & 6600 & 9100 & 12600 \\
$\mathrm{PM}_{2.5}\left[\mu \mathrm{g} \mathrm{m}^{-3}\right]$ & 90 & 24 & 47 & 79 & 116 & 194 \\
$\mathrm{CS}\left[10^{-2} \mathrm{~s}^{-1}\right]$ & 5.4 & 1.7 & 3.0 & 4.1 & 5.6 & 7.7 \\
\hline
\end{tabular}

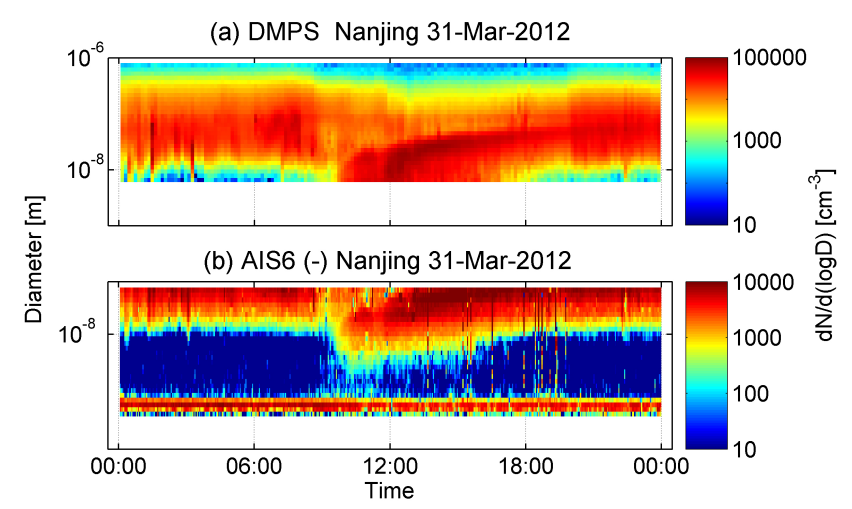

Fig. 4. Example of a typical particle formation event seen with both the AIS (b) and the DMPS (a). Note the difference in color scale. Typical for particle formation events observed at the SORPES-NJU station is the gap visible in the AIS data, indicating that the neutral pathway dominates particle formation.

Table 3. Event statistics.

\begin{tabular}{lrrr}
\hline & $\begin{array}{r}\text { Event } \\
\text { days }\end{array}$ & $\begin{array}{r}\text { Non-event } \\
\text { days }\end{array}$ & $\begin{array}{r}\text { Undefined/ } \\
\text { no data }\end{array}$ \\
\hline Nov (18-30) & 1 & 5 & 8 \\
Dec & 4 & 23 & 4 \\
Jan & 7 & 13 & 11 \\
February & 7 & 12 & 10 \\
March & 7 & 12 & 16 \\
\hline TOTAL & 26 & 65 & 45 \\
\hline
\end{tabular}

a noticeable gap between the cluster band below $2 \mathrm{~nm}$ and what is informally called the nucleation "banana" (Fig. 4). The growth of nucleated particles could be observed over several hours after the initial onset of particle formation. New particle formation was observed on 26 days during the measurement period (Table 3), which corresponds to a nucleation probability of about $20 \%$. Nucleation was observed to take place during all months of our measurements, with somewhat less activity during November and December. (a)
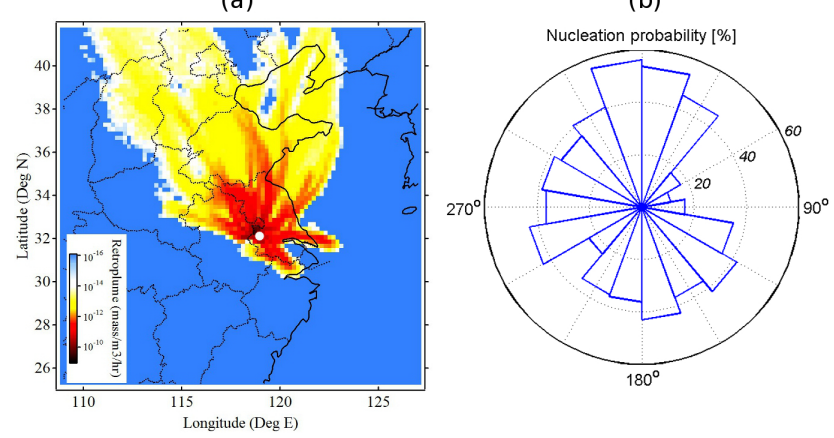

Fig. 5. (a) 1-day footprint retroplume for event days in a map of eastern China. The measurement site is marked by a white dot. (b) Observed nucleation probability at the site as a function of the direction of the incoming air mass.

The wind direction and the origin and history of the incoming air masses have been found to play a significant role in new particle formation (Sogacheva et al., 2005; Dal Maso et al., 2007). Figure 5 summarizes the situation at the SORPESNJU site for the measurement period. The nucleation probability was quite high (around and over $40 \%$ ) for most wind directions (Fig. 5b), while being rather low for the easterly winds between about $45^{\circ}$ and $100^{\circ}$. Incidentally, the direction of the low nucleation probability is also the prevailing wind direction (see Fig. 2), amounting to the total nucleation probability of about $20 \%$, as noted earlier. Figure 5 a shows the 1-day retroplumes calculated by the Lagrangian dispersion model HYSPLIT for the nucleation event days recorded during the measurement period. It is noteworthy that events were only observed when air masses originated from the NNE half of the map (300-120 ${ }^{\circ}$ in terms of wind directions). It seems plausible that air masses from SSW typically pass over heavily polluted Nanjing and adjacent industrial areas and are therefore so saturated with particles that the high condensation sink makes new particle formation unlikely. The accumulation mode in Fig. 3d with the highest concentrations in the south supports this view. A striking feature of Fig. 5a is the "gap" to the east (ca. 100$130^{\circ}$ ). This gap is home to Shanghai, Suzhou, and Wuxi essentially all major cities in the YRD. Ding et al. (2013a) 
found an important potential source contribution from this city cluster to trace gases and aerosol mass concentrations measured at the SORPES-NJU site. Figure 5a thus states that practically no new particle formation was observed in air masses coming from the cities of the YRD, from where the air masses are often associated with high particle loadings (Ding et al., 2013a). It has to be underlined that Fig. 5a and $b$, while both providing information on the incoming air masses, represent different aspects of the situation. The retroplumes in Fig. 5a illustrate a regional picture of the transport of air masses during the last $24 \mathrm{~h}$ before the nucleation event, while the wind directions in Fig. 5b show the local situation during the event.

To shed further light on the interplay between nucleated and larger particles, we compared particle number concentrations in two size regimes to those observed in a few other sites (Table 4). In the diameter range 10-100 nm, i.e., where new particles should contribute, Gao et al. (2009) observed over 28000 particles $\mathrm{cm}^{-3}$ outside Shanghai, while we saw only 13000 particles $\mathrm{cm}^{-3}$ outside Nanjing. Part of this difference might well be explained by the different measurement periods, yet the theory that high preexisting particle loads suppresses nucleation seems a more plausible explanation: between 100 and $500 \mathrm{~nm}$, the SORPES-NJU site was exposed to almost fourfold particle concentrations compared with the Shanghai site. Considering the prevailing easterly winds (i.e., from Shanghai and YRD), it is also fairly obvious that much of the accumulation mode observed at the SORPES-NJU site has its origin in the YRD.

\subsubsection{Particle formation rate and the role of ions}

We determined the formation rate of $6 \mathrm{~nm}$ particles, $J_{6}$, for each nucleation event separately. The median value of $J_{6}$ was equal to $0.82 \mathrm{~cm}^{-3} \mathrm{~s}^{-1}$, and the corresponding 25 th and 75 th percentiles were 0.51 and $1.23 \mathrm{~cm}^{-3} \mathrm{~s}^{-1}$. To gain more insight into the actual nucleation rate and its connection with ions, we further estimated the formation rate of $2 \mathrm{~nm}$ particles, following the method outlined by Kulmala et al. (2012). We found that the median value of $J_{2}$ was $23.9 \mathrm{~cm}^{-3} \mathrm{~s}^{-1}$, i.e., about 30 times the value of $J_{6}$, and that the 25 th and 75 th percentiles of $J_{2}$ were equal to 14.8 and $56.8 \mathrm{~cm}^{-3} \mathrm{~s}^{-1}$, respectively. The estimated values of $J_{2}$ should be interpreted with care, since the conversion from $J_{6}$ to $J_{2}$ is known to be sensitive to the size-dependent growth profile of sub $6 \mathrm{~nm}$ particles (e.g., Korhonen et al., 2011), and we did not have accurate information on this profile.

The particle formation rates observed at the SORPES-NJU station are clearly higher than those typically observed in most remote or moderately polluted environments (e.g., Kulmala et al., 2004; Dal Maso et al., 2007; Asmi et al., 2011). In urban environments, particle formation rates tend to be larger than $1 \mathrm{~cm}^{-3} \mathrm{~s}^{-1}$, even though the reported values span over two orders of magnitude, depending on location, day and the size at which the formation rate has been determined (e.g., Kulmala et al., 2004; Mönkkönen et al., 2005; Qian et al., 2007; Salma et al., 2011). A similar variability is also reflected in measurement conducted in China. The formation rate of $3 \mathrm{~nm}$ particles has been reported to range from 3.3 to $81 \mathrm{~cm}^{-3} \mathrm{~s}^{-1}$ in Beijing (Wu et al., 2007), from 0.5 to $5.2 \mathrm{~cm}^{-3} \mathrm{~s}^{-1}$ in the Pearl River Delta (Liu et al., 2008), and from 0.7 to $73 \mathrm{~cm}^{-3} \mathrm{~s}^{-1}$ with a mean of $8.0 \mathrm{~cm}^{-3} \mathrm{~s}^{-1}$ in the North China Plain (Shen et al., 2011). The formation rates of $5.5 \mathrm{~nm}$ particles were found to vary between about 1 and $10 \mathrm{~cm}^{-3} \mathrm{~s}^{-1}$ at a mountain site in Hong Kong (Guo et al., 2012), whereas formation rates below $1 \mathrm{~cm}^{-3} \mathrm{~s}^{-1}$ were reported for $10 \mathrm{~nm}$ particles in urban Shanghai (Du et al., 2012). The new particle formation rates observed at the SORPES-NJU station appear to be in the middle to upper ranges of those observed elsewhere in China until present day.

Comparing the values of $J_{2}$ and $J_{6}$ between ions and total particles (ions + neutral particles) provides insights into the role of ions in the new particle formation process. The mean formation rate of $2 \mathrm{~nm}$ ions was $0.02 \mathrm{~cm}^{-3} \mathrm{~s}^{-1}$ at our site (see Table 6), which is among the lowest values reported in the literature (Hirsikko et al., 2011). The ratio between charged and total $2 \mathrm{~nm}$ particle formation rates had a mean value of $0.2 \%$ (the median was $0.07 \%$ ), much lower than the typical values between about 1 and $30 \%$ at different sites in Europe (Manninen et al., 2010). The formation rate of $6 \mathrm{~nm}$ ions was somewhat higher than that of $2 \mathrm{~nm}$ ions, and the ratio between charged and total $6 \mathrm{~nm}$ particle formation rates had a mean of $7.7 \%$ (median $4 \%$ ) (Table 6). These features can be explained by aerosol dynamics in the sub- $6 \mathrm{~nm}$ diameter size range: concentrations of neutral particles are continually being reduced during their growth from 2 to $6 \mathrm{~nm}$ due to their coagulation with larger preexisting particles (Lehtinen et al., 2007), whereas concentrations of ions are also affected by ion-ion recombination and ion-aerosol attachment taking place in the sub- $6 \mathrm{~nm}$ size range (Kerminen et al., 2007; Leppä et al., 2009). These processes frequently create an apparent "gap" in ion concentrations between about $2 \mathrm{~nm}$ and a few nanometers, as seen in Fig. 4, and also explain the observed increase in the ratio of $J_{\text {ion }}$ to $J_{\text {total }}$ from 2 to $6 \mathrm{~nm}$ (Table 6). Consistent with observations by most others in continental boundary layers (Hirsikko et al., 2011; Kulmala et al., 2013), our measurements indicate only a minor role of ions in the new particle formation process.

An intriguing feature in the behavior of ions is shown in Fig. 6a: there is a small, but we believe important, difference in cluster ion concentrations $(<2 \mathrm{~nm})$ between the event and non-event days. We can see that cluster ions concentrations increased during the event days before the new particle formation started, with peak concentration observed on average around 04:00 LT, several hours before the sunrise. A noteworthy detail is that the subsequent decline in the cluster ion concentration was then accompanied by a slight increase in the intermediate ion concentration (Fig. 6b). When the new particle formation started properly between about 
Table 4. Aerosol numbers $\left(\mathrm{cm}^{-3}\right)$ in Nanjing and Shanghai compared to other cities around the world.

\begin{tabular}{llll}
\hline & $10-100 \mathrm{~nm}$ & $100-500 \mathrm{~nm}$ & \\
\hline Shanghai, China & 28511 & 1676 & Gao et al. (2009) \\
Nanjing, China & 13000 & 6200 & This work \\
Alkmaar, Netherlands & 18300 & 2120 & Ruuskanen et al. (2001) \\
Erfurt, Germany & 17700 & 2270 & Wichmann and Peters (2000) \\
Helsinki, Finland & 16200 & 973 & Ruuskanen et al. (2001) \\
Pittsburgh, PA, USA & 14300 & 2170 & Stanier et al. (2004) \\
Atlanta, GA, USA & 21400 & n/a & Woo et al. (2001) \\
\hline
\end{tabular}

Table 5. Event characteristics.

\begin{tabular}{|c|c|c|c|c|c|c|}
\hline & Mean & 5th percentile & 25th percentile & Median & 75th percentile & 95th percentile \\
\hline$J_{6}\left[\mathrm{~cm}^{-3} \mathrm{~s}^{-1}\right]$ (observed) & 1.1 & 0.25 & 0.5 & 0.8 & 1.2 & 3.5 \\
\hline$J_{2}\left[\mathrm{~cm}^{-3} \mathrm{~s}^{-1}\right]$ (calculated) & 33.2 & 2.6 & 14.8 & 23.9 & 56.8 & 75.6 \\
\hline GR 6-30 nm (DMPS) $\left[\mathrm{nm} \mathrm{h}^{-1}\right]$ & 8.5 & 4.5 & 6.1 & 6.9 & 10.9 & 15.4 \\
\hline GR 3-7 nm (AIS) $\left[\mathrm{nm} \mathrm{h}^{-1}\right]$ & 6.3 & 2.4 & 4.5 & 5.9 & 7.9 & 11.8 \\
\hline GR 7-30 nm (AIS) $\left[\mathrm{nm} \mathrm{h}^{-1}\right]$ & 8.0 & 3.5 & 5.2 & 6.7 & 8.2 & 16.0 \\
\hline $\operatorname{CS}\left[10^{-2} \mathrm{~s}^{-1}\right]$ & 2.4 & 0.9 & 2.0 & 2.5 & 3.1 & 3.8 \\
\hline$Q\left[10^{6} \mathrm{~cm}^{-3} \mathrm{~s}^{-1}\right]$ & 3.8 & 1.0 & 2.2 & 3.0 & 5.5 & 7.5 \\
\hline
\end{tabular}

$\mathrm{GR}=$ growth rate, $Q=$ source of condensable vapors
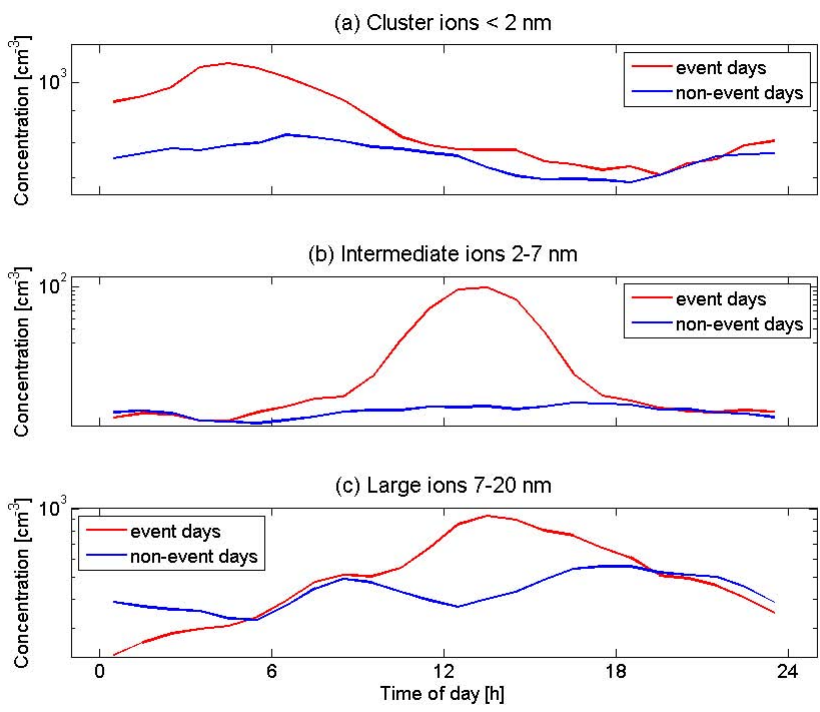

Fig. 6. Median diurnal cycles for different ion sizes, separated by days with and without new particle formation (event/non-event days). (a) Cluster ions $<2 \mathrm{~nm}$. (b) Intermediate ions $2-7 \mathrm{~nm}$. (c) Large ions $7-20 \mathrm{~nm}$. Concentrations refer to the sum of positive and negative ions.

09:00 LT and 11:00 LT (Fig. 6b), the cluster ion concentration had almost returned to the level typical for non-event days. Since the new particle formation occurred 5 to $7 \mathrm{~h}$ after the observed peak in the cluster ion concentration, it is highly unlikely that the increased cluster ion concentrations during the night could have had a direct effect on new particle formation, especially because the role of ion-induced nucleation seemed to be rather small. A more feasible explanation is that the ion cluster behavior correlated with processes or conditions that directly or indirectly favor new particle formation.

\subsubsection{Particle growth and $\mathrm{CCN}$ production}

The extremely low concentrations of the smallest $(<3 \mathrm{~nm}$ diameter) ions (see the gap in Fig. 4) made it impossible to estimate the growth rate of sub-3 nm particles. For particles between 3 and $7 \mathrm{~nm}$ in diameter, the median growth rate was $5.9 \mathrm{~nm} \mathrm{~h}^{-1}$ based on the AIS measurements, with 25th and 75th percentiles of 4.4 and $7.9 \mathrm{~nm} \mathrm{~h}^{-1}$, respectively (Table 5). The corresponding median growth rate (and percentiles) for 7-30 nm particles was $6.7 \mathrm{~nm} \mathrm{~h}^{-1}$ (5.2 and $8.2 \mathrm{~nm} \mathrm{~h}^{-1}$ ). Based on the DMPS data, the median growth rate of 6-30 nm particles was $6.9 \mathrm{~nm} \mathrm{~h}^{-1}$ with percentiles of 6.1 and $10.9 \mathrm{~nm} \mathrm{~h}^{-1}$, and particles larger than $30 \mathrm{~nm}$ in diameter grew almost as fast (median $6.6 \mathrm{~nm} \mathrm{~h}^{-1}$ ). These values are well within the range of observations made in Europe (e.g., Manninen et al., 2010). In China, urban measurements have typically yielded somewhat smaller new particle growth rates, with typical mean values between about 3 and $6 \mathrm{~nm} \mathrm{~h}^{-1}$ (e.g., Yao et al., 2010; Du et al., 2012; Gao et al., 2012). Observed particle growth rates in Beijing show a large variability, ranging from below $1 \mathrm{~nm} \mathrm{~h}^{-1}$ to values $>30 \mathrm{~nm} \mathrm{~h}^{-1}$ (Wu et al., 2007; Wang et al., 2011, Zhang et al., 2011; Gao et al., 2012). In suburban Shanghai, Gao et al. (2009) found a mean 
Table 6. Ion and total nucleation rates at different diameters, mean values.

\begin{tabular}{lrrrr}
\hline & AIS (ions) & DMPS & AIS/DMPS & AIS/DMPS (25/50/75th percentiles) \\
\hline$J_{2}\left[\mathrm{~cm}^{-3} \mathrm{~s}^{-1}\right]$ & 0.02 & $33.2^{*}$ & 0.002 & $0.0003 / 0.00075 / 0.0015$ \\
$J_{6}\left[\mathrm{~cm}^{-3} \mathrm{~s}^{-1}\right]$ & 0.05 & 1.1 & 0.077 & $0.0227 / 0.0399 / 0.0626$ \\
\hline
\end{tabular}

*calculated value

particle growth rate of $6.4 \mathrm{~nm} \mathrm{~h}^{-1}$, which is quite close to our median value.

The relatively large particle formation and growth rates observed at the SORPES-NJU station suggest a potentially large contribution of nucleation to the regional $\mathrm{CCN}$ budget. By following the approach outlined by Kerminen et al. (2012), we calculated the relative and absolute increases in $\mathrm{CCN}$ number concentrations, following atmospheric nucleation by using the total number concentrations of particles larger than $50,80,100$ or $150 \mathrm{~nm}$ in diameter as proxies for $\mathrm{CCN}$ at different water supersaturation levels (Table 7). Typical absolute increases in $\mathrm{CCN}$ number concentrations during the nucleation event days were several thousand particles per $\mathrm{cm}^{3}$. These values are comparable to those reported earlier in Beijing (Wiedensohler et al., 2009; Yue et al., 2011), but considerably larger than those measured elsewhere in continental boundary layers until present day (see Kerminen et al., 2012, and references therein). In spite of the high preexisting $\mathrm{CCN}$ number concentrations at the SORPES-NJU station, the nucleation events enhanced $\mathrm{CCN}$ number concentrations on the order of $100 \%$, similar to what has been observed in more remote environments (Kerminen et al., 2012). We conclude that atmospheric nucleation is a potentially large contributor to CCN and thereby on aerosol indirect effects over the YRD and similar regions, warranting future measurements and modeling studies on this subject.

\subsubsection{Predictions}

Just as the sulfuric acid proxy is a useful tool in the absence of sulfuric acid measurements, a simple parameter for predicting whether nucleation takes place or not based on a number of key variables would be a useful tool for e.g., modeling purposes. McMurry et al. (2005) developed such a parameter (which they named new particle formation criterion) and tested it for the conditions in Atlanta. Using the sulfuric acid proxy for Atlanta, this criterion can be rewritten as

$L^{\prime} \sim \frac{\mathrm{CS}^{1.53} \cdot \mathrm{RH}^{1.92}}{\text { Radiation }^{1.10} \cdot\left[\mathrm{SO}_{2}\right]^{0.69} \cdot T^{0.5}}$.

If $L^{\prime}$ is smaller than a certain threshold value, particle formation should be observed. Considering the application of this parameter to the Nanjing conditions, we notice that Eq. (5) is actually not consistent with the data presented in Fig. 7. The equation treats $\mathrm{SO}_{2}$ as a factor favoring particle formation, while Fig. $7 \mathrm{~b}$ clearly shows that event days show lower
$\mathrm{SO}_{2}$ concentrations than non-event days. Moreover, no correlation could be observed between temperature $T$ and nucleation probability (not shown) in Nanjing. Thus, a parameter reflecting observations at the SORPES-NJU station should have the following form:

$$
L^{\prime \prime} \sim \frac{\mathrm{CS}^{a} \cdot\left[\mathrm{SO}_{2}\right]^{b} \cdot \mathrm{RH}^{c}}{\text { Radiation }^{d}}
$$

where $a, b, c$, and $d$ are fitting parameters having positive values. These parameters can then be optimized in such a way that the overlap between data points representing event and non-event days becomes as small as possible. For the measurement period, the smallest overlap found was $10 \%$, which means that the lowest $10 \%$ of the non-event day data points and the highest $10 \%$ of the event day data points overlapped. For the best separation, the values of the fitting parameters were $a=1.6, b=0.6, c=5.6$, and $d=3.5$ (see Fig. 9a). At face value, these exponents are well within reason. The exponent for $\mathrm{SO}_{2}$ is quite small, indicating the dual role of $\mathrm{SO}_{2}$, as discussed above, and highlighting that, ultimately, actual $\mathrm{SO}_{2}$ concentrations are of minor importance under heavily polluted conditions. The remaining variables, $\mathrm{CS}, \mathrm{RH}$, and radiation, and their exponents roughly represent $\left[\mathrm{H}_{2} \mathrm{SO}_{4}\right]^{-3}$ (see Eq. 4) only without $\mathrm{SO}_{2}$, again pointing out that the role of $\mathrm{SO}_{2}$ in the sulfuric acid proxy is the main source of uncertainty. Linking our empirical criterion to $\left[\mathrm{H}_{2} \mathrm{SO}_{4}\right]^{-3}$ is a significant departure from the criterion by McMurry et al. (2005), where sulfuric acid had the exponent of -1 . However, while separating events from non-events very well, it has to be understood that these purely empirical exponents do not necessarily provide deeper insight into the formation process. The reason for this lies in the very nature of the optimization process in which they were found. This process was not concerned with typical behavior. Instead, the exponents are likely to be significantly determined by data points which are far away from median values. However, at $90 \%$ separation, this empirical criterion is an easy and reliable way to predict a main parameter of particle formation.

Similar to the above approaches for sulfuric acid and particle formation criterion, an attempt can be made to describe the particle formation rate in terms of the same parameters:

$$
J_{6, \text { theo }}=k_{\mathrm{NPF}} \cdot \text { Radiation }^{a}\left[\mathrm{SO}_{2}\right]^{b} \cdot \mathrm{RH}^{c} \cdot \mathrm{CS}^{d} .
$$

In this equation, $k_{\mathrm{NPF}}$ is a constant factor, $J_{6, \text { theo }}$ is given in units $\mathrm{cm}^{-3} \mathrm{~s}^{-1}$, radiation is given in $\mathrm{W} \mathrm{m}^{-2},\left[\mathrm{SO}_{2}\right]$ is given 
Table 7. Increase in $\mathrm{CCN}$ concentration during particle formation days. The number of particles above a certain size (CCN threshold in this table) was used as a $\mathrm{CCN}$ proxy. The percentages behind the mean and median values give the mean and, respectively, median increase in percent.

\begin{tabular}{lllll}
\hline CCN threshold & 25th percentile & Mean (\%) & Median $(\%)$ & 75th percentile \\
\hline$>50 \mathrm{~nm}\left[\mathrm{~cm}^{-3}\right]$ & 5400 & $6950(106)$ & $7900(99)$ & 9400 \\
$>80 \mathrm{~nm}\left[\mathrm{~cm}^{-3}\right]$ & 3500 & $4680(124)$ & $5000(83)$ & 5800 \\
$>100 \mathrm{~nm}\left[\mathrm{~cm}^{-3}\right]$ & 2800 & $3430(137)$ & $3600(73)$ & 4000 \\
$>150 \mathrm{~nm}\left[\mathrm{~cm}^{-3}\right]$ & 1200 & $1730(134)$ & $1550(98)$ & 1700 \\
\hline
\end{tabular}
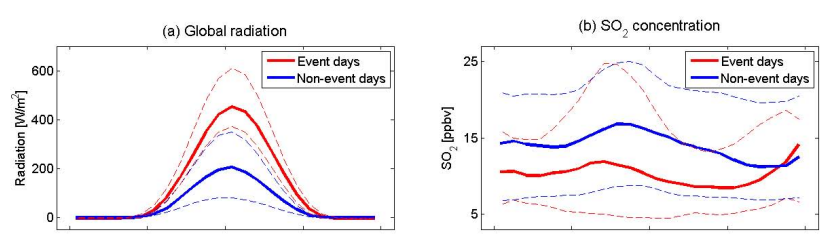

(c) Condensational sink
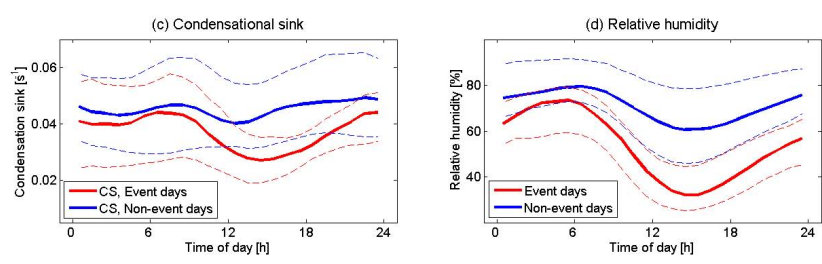

Fig. 7. Diurnal cycles of median values of relevant parameters for days with and without new particle formation. The dashed lines represent the respective quartiles. (a) Global radiation. (b) $\mathrm{SO}_{2}$ concentration. (c) Condensational sink. (d) Relative humidity.
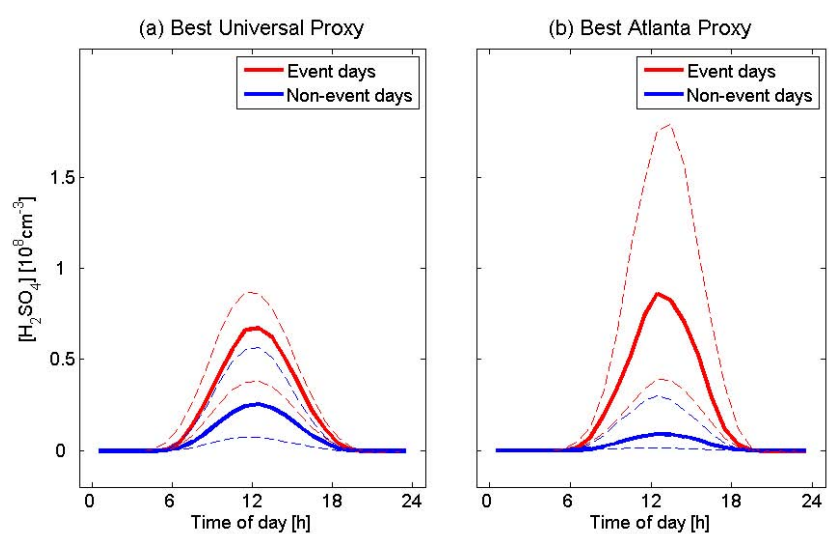

Fig. 8. Diurnal cycles of median values of two sulfuric acid proxies, according to Mikkonen et al. (2011). Separated for days with and without new particle formation. The dashed lines represent the respective quartiles. (a) Best universal proxy. (b) Best Atlanta proxy.

in ppb, $\mathrm{RH}$ is given in $\%$, and CS is given in $\mathrm{s}^{-1}$. The prefactor and the exponents $a, b, c$, and $d$ can then be optimized in such a way (allowing for positive and negative values for all exponents) that $J_{6 \text {,theo }}$ is as close to the measured formation rate $J_{6 \text {,meas }}$ as possible (least squares fit). The best fit obtained this way gave $k_{\mathrm{NPF}}=2.75 \times 10^{-13}, a=3.0, b=1.0$, $c=0.3$, and $d=-1.9$. With these values, theoretical and measured formation rates can be matched with $R^{2}=0.77$ (see Fig. 9b). The temperature was not included in Eq. (7) because our tests showed that including this parameter did not produce a better fit. Just as with the particle formation criterion (Eq. 6), the nucleation rate again shows the exponents for radiation and condensational sink with a factor of roughly 3 when compared to the Atlanta sulfuric acid proxy. Compared with the criterion for occurrence of nucleation (Eq. 6) and sulfuric acid proxy (Eq. 4), RH seemed to play almost no role in actual particle formation rate, indicating that its role in Eq. (6) is to act first and foremost as an indicator of general conditions with relation to potential particle formation. $\mathrm{SO}_{2}$, with a different subset of data, has changed the sign of its exponent. In short, the analysis shows formation to be determined by radiation as the main driving force and condensation sink as the main obstacle. This parameterization provides a relatively simple way to predict formation rates. Given actual measurements of sulfuric acid (instead of a proxy) and a lower aerosol detection limit, this analysis can also provide a link between sulfuric acid and nucleation rate of the form $J \sim\left[\mathrm{H}_{2} \mathrm{SO}_{4}\right]^{n}$, which provides insight into the formation mechanism. With the current state of instrumentation, the tentative $n \approx 3$ has to be considered as rather speculative and unreliable, even if recent results by Wang et al. (2011) show that, in China, $n$ can significantly exceed the typical range between 1 (cluster activation) and 2 (kinetic nucleation).

\section{Summary and conclusions}

The Station for Observing Regional Processes of the Earth System at Nanjing University (SORPES-NJU) is set up to measure atmospheric processes continuously and on a longterm basis. As part of the station's operations, aerosol and air ion measurements started in the end of 2011. In this paper, we present the first data from these measurements, giving a broad and in-depth analysis of the data with a special focus on ions, new particle formation, its conditions, and its effects on $\mathrm{CCN}$ concentrations.

From the middle of November 2011 to the end of March 2012, an air ion spectrometer (AIS) and a differential mobility particle sizer (DMPS) monitored the air ion (0.8$42 \mathrm{~nm})$ and aerosol $(6-800 \mathrm{~nm})$ populations at a site outside 

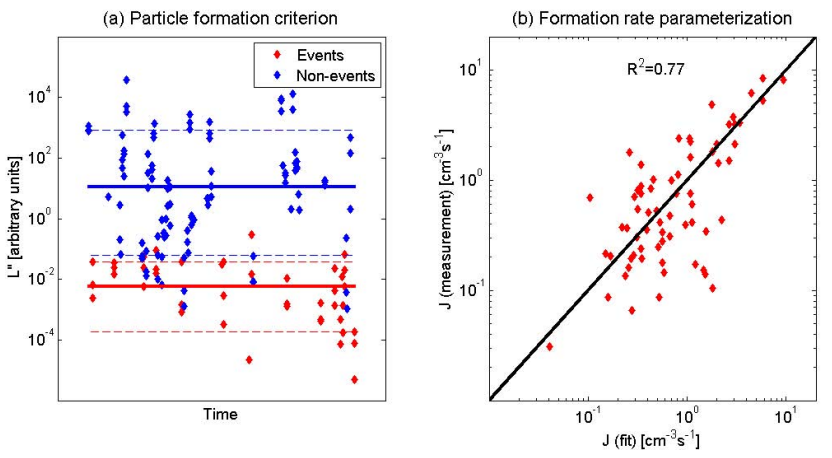

Fig. 9. Description of central particle formation characteristics as a function of observations of radiation, condensational sink, relative humidity, and $\mathrm{SO}_{2}$ concentration. See respective sections for equations. (a) Particle formation criterion with quartiles. Note that the upper and lower quartile for events and non-events, respectively, do not overlap. (b) Particle formation rate $J_{6}$ parameterization with best fit. $R^{2}=0.77$.

Nanjing in the Yangtze River Delta in eastern China. For the total particle concentration, the measured mean value of $2.3 \times 10^{4} \mathrm{~cm}^{-3}$ is on the same order of magnitude as similar observations in China, Europe, and the US (see Table 6). Interestingly, a much larger fraction of the total particle number was due to larger particles when comparing Nanjing to other (urban) locations, resulting in high $\mathrm{PM}_{2.5}$ loads with a mean value of $90 \mu \mathrm{g} \mathrm{m}^{-3}$, well above the annual national limit of $35 \mu \mathrm{g} \mathrm{m}^{-3}$ and even above the daily average limit of $75 \mu \mathrm{g} \mathrm{m}^{-3}$. Observations give reason to assume that high accumulation mode concentrations are mainly imported from pollution sources east of Nanjing, i.e., from the YRD. Accordingly, not a single particle formation event was observed when air masses came in from the YRD.

New particle formation was observed for 26 days, resulting in a nucleation probability of almost $20 \%$. Typical growth rates of newly formed particles were between 6 and $7 \mathrm{~nm} \mathrm{~h}^{-1}$, which falls well within the range observed in both Europe and China (e.g., Manninen et al., 2010). The observed formation rate of $6 \mathrm{~nm}$ particles had a mean value of $1.1 \mathrm{~cm}^{-3} \mathrm{~s}^{-1}$ and the nucleation events increased particle number concentration, on average, by more than $17000 \mathrm{~cm}^{-3}$. Using the number of particles above a certain size as a CCN proxy, we found that $\mathrm{CCN}$ concentration roughly doubled during nucleation event days, corresponding to $1700-7000$ new $\mathrm{CCN}$ per $\mathrm{cm}^{3}$. These numbers show that new particle formation has a very significant impact on $\mathrm{CCN}$ concentrations in the YRD and likely so in similar environments. It is therefore essential to predict particle formation probability and intensity to estimate $\mathrm{CCN}$ concentrations, which play a central role in cloud formation and, ultimately, climate.

We measured the first comprehensive data set on air ion concentrations in China. As has been observed in Europe, we found a constantly present ion cluster population in the diam- eter range $0.8-2 \mathrm{~nm}$. The median total ion concentration was $770 \mathrm{~cm}^{-3}$ with quartiles of $600 \mathrm{~cm}^{-3}$ and $970 \mathrm{~cm}^{-3}$, indicating quite small variability in the small ion concentration. The formation rate of $2 \mathrm{~nm}$ ions was at the low end of values reported in the literature, contributing only $0.2 \%$ to the total formation rate of $2 \mathrm{~nm}$ particles. We conclude that the contribution of ions to atmospheric new particle formation was almost negligible in air masses affecting our measurements, supporting the current view that neutral pathways dominate new particle formation in continental boundary layers.

To this end, a comparative analysis of the conditions during event and non-event days was performed. We found that radiation and relative humidity are the most decisive factors while the condensational sink has less impact. While $\mathrm{SO}_{2}$ is necessary for sulfuric acid formation, high $\mathrm{SO}_{2}$ concentrations did not coincide with particle formation. Instead, the role of $\mathrm{SO}_{2}$ as a pollution indicator outweighed its active role as a sulfuric acid precursor. Based on these observations, an empirical particle formation criterion was developed that predicted the occurrence of new particle formation with an accuracy of $90 \%$. This criterion is largely determined by radiation and relative humidity, with $\mathrm{SO}_{2}$ concentration and condensation sink having much less impact, just as the analysis of the single variables suggested. This criterion significantly differs from an earlier one by McMurry et al. (2005), which was optimized for conditions in the city of Atlanta. This suggests that different environments cannot be covered by one criterion. Similarly, the formation rate of $6 \mathrm{~nm}$ particles, $J_{6}$, was parameterized based on observations. For $J_{6}$, radiation and condensational sink were the most important parameters, while the relative humidity could almost be neglected. We were able to optimize this parameterization until it correlated with the observations with an $R^{2}$ of 0.77 . Combining the nucleation criterion and the formation rate parameterization, it is possible to predict particle formation based on a few simple measurements.

While the data presented here are the most comprehensive study on aerosols and nucleation in the Yangtze River Delta and while they illustrate the power of integrated atmospheric measurements, they also stress the need for more observations. One focus of future measurements has to be on sulfuric acid. While sulfuric acid proxies are available, their reliability is only limited, especially in the light of our findings regarding the nucleation criterion. However, considering these proxies and our $J_{6}$ parameterization, one is lead to speculate that the sulfuric acid exponent might be well over 2 . This would mean that neither the kinetic nor the activation approach could explain all particle formation at the site. While this is highly speculative with the currently available data, it nevertheless stresses the need for a closer look at sulfuric acid. Besides this, other condensable species have to be considered, since particle formation and growth intensity during events suggest much higher vapor concentrations than the proxies alone could explain. 
With this choice of location, the SORPES-NJU station takes a step away from the urban bias in Chinese aerosol research. The station's air ion measurements allow the direct observation of nucleation and thus extend the previous observation range in China and Asia. Besides individual findings such as, for example, the role of ions in nucleation, these early results can be summarized by two major observations. First, results from Europe and North America cannot simply be applied globally. The role of sulfuric acid, its contribution to the formation and growth, its expression through proxies, the role of ions - these are just some of the major areas where we found differences. Secondly, much variation with respect to aerosols and particle formation can be found within China: aerosol population characteristics differ significantly even between Nanjing and Shanghai, two cities merely $300 \mathrm{~km}$ apart. To understand and quantify aerosols and their formation in China and Asia (and ultimately globally), much more research is necessary, especially comprehensive long-term measurements in strategic locations.

Acknowledgements. This work was funded by the National Basic Research Program 973 Project of China (2010CB428500), National Natural Science Foundation of China (no. 41275129/D0510), the Jiangsu Provincial 2011 Program (Collaborative Innovation Center of Climate Change), the Academy of Finland projects (1118615, 139656), and the European Commission via ERC Advanced Grant ATM-NUCLE. The SORPES-NJU station was supported by the 985 program and the Fundamental Research Funds for Central Universities in China. We appreciate the contributions of L. Zheng, Y. Xie, L. Jin, and Z. Peng in the maintenance of the trace gases and meteorological instruments at the station.

Edited by: S. M. Noe

\section{References}

Asmi, E., Kivekäs, N., Kerminen, V.-M., Komppula, M., Hyvärinen, A.-P., Hatakka, J., Viisanen, Y., and Lihavainen, H.: Secondary new particle formation in Northern Finland Pallas site between the years 2000 and 2010, Atmos. Chem. Phys., 11, 12959-12972, doi:10.5194/acp-11-12959-2011, 2011.

Bellouin, N., Jones, A., Haywood, J., and Christopher, S. A.: Updated estimate of aerosol direct radiative forcing from satellite observations and comparison against the Hadley Centre climate model, J. Geophys. Res.-Atmos., 113, D10205, doi:10.1029/2007JD009385, 2008.

Boy, M., Kulmala, M., Ruuskanen, T. M., Pihlatie, M., Reissell, A., Aalto, P. P., Keronen, P., Dal Maso, M., Hellen, H., Hakola, H., Jansson, R., Hanke, M., and Arnold, F.: Sulphuric acid closure and contribution to nucleation mode particle growth, Atmos. Chem. Phys., 5, 863-878, doi:10.5194/acp-5-863-2005, 2005.

Dal Maso, M., Sogacheva, L., Aalto, P. P., Riipinen, I., Komppula, M., Tunved, P., Korhonen, L., Suur-Uski, V., Hirsikko, A., Kurtén, T., Kerminen, V.-M., Lihavainen, H., Viisanen, Y., Hansson, H.-C., and Kulmala, M.: Aerosol size distribution measurements at four Nordic field stations: identification, analysis and trajectory analysis of new particle formation bursts, Tellus B, 59, 350-361, doi:10.1111/j.1600-0889.2007.00267.x, 2007.

Ding, A. J., Fu, C. B., Yang, X. Q., Sun, J. N., Zheng, L. F., Xie, Y. N., Herrmann, E., Nie, W., Petäjä, T., Kerminen, V.-M., and Kulmala, M.: Ozone and fine particle in the western Yangtze River Delta: an overview of $1 \mathrm{yr}$ data at the SORPES station, Atmos. Chem. Phys., 13, 5813-5830, doi:10.5194/acp-13-58132013, 2013a.

Ding, A. J., Fu, C. B., Yang, X. Q., Sun, J. N., Petäjä, T., Kerminen, V.-M., Wang, T., Xie, Y., Herrmann, E., Zheng, L. F., Nie, W., Liu, Q., Wei, X. L., and Kulmala, M.: Intense atmospheric pollution modifies weather: a case of mixed biomass burning with fossil fuel combustion pollution in eastern China, Atmos. Chem. Phys., 13, 10545-10554, doi:10.5194/acp-1310545-2013, 2013b.

Ding, A. J., Wang, T., and Fu, C. B.: Transport characteristics and origins of carbon monoxide and ozone in Hong Kong, South China, J. Geophys. Res., 118, 9475-9488, doi:10.1002/jgrd.50714, 2013c.

Draxler, R. R. and Hess, G. D.: An Overview of the HYSPLIT_4 Modeling System for Trajectories, Dispersion, and Deposition, Aust. Meteorol. Mag., 47, 295-308, 1998.

Du, J. F., Cheng, T. T., Zhang, M., Chen, J. M., He, Q. S., Wang, X. M., Zhang, R. J., Tao, J., Huang, G. H., Li, X., and Zha, S. P.: Aerosol Size Spectra and Particle Formation Events at Urban Shanghai in Eastern China, Aerosol Air Qual. Res., 12, 13621372, doi:10.4209/aaqr.2011.12.0230, 2012.

Fiedler, V., Dal Maso, M., Boy, M., Aufmhoff, H., Hoffmann, J., Schuck, T., Birmili, W., Hanke, M., Uecker, J., Arnold, F., and Kulmala, M.: The contribution of sulphuric acid to atmospheric particle formation and growth: a comparison between boundary layers in Northern and Central Europe, Atmos. Chem. Phys., 5, 1773-1785, doi:10.5194/acp-5-1773-2005, 2005.

Gao, J., Wang, J., Cheng, S. H., Xue, L. K., Yan, H. Z., Hou, L. J., Jiang, Y. Q., and Wang, W. X.: Number concentration and size distributions of submicron particles in Jinan urban area: Characteristics in summer and winter, J. Environ. Sci., 19, 1466-1473, 2007.

Gao, J., Wang, T., Zhou, X. H., Wu, W., and Wang, W. $\mathrm{X}$.: Measurement of aerosol number size distributions in the Yangtze River Delta in China: Formation and growth of particles under polluted conditions, Atmos. Environ., 43, 829-836, doi:10.1016/j.atmosenv.2008.10.046, 2009.

Gao, J., Chai, F. H., Wang, T., and Wang, W. X.: Particle number size distribution and new particle formation (NPF) in Lanzhou, Western China, Particuology, 9, 611-618, doi:10.1016/j.partic.2011.06.008, 2011.

Gao, J., Chai, F. H., Wang, T., Wang, S. L., and Wang, W. X.: Particle number size distribution and new particle formation: New characteristics during the special pollution control period in Beijing, J. Environ. Sci., 24, 14-21, doi:10.1016/S10010742(11)60725-0, 2012.

Gong, Y. G., Hu, M., Cheng, Y. F., Su, H., Yue, D. L., Liu, F., Wiedensohler, A., Wang, Z. B., Kalesse, H., Liu, S., Wu, Z. J., Xiao, K. T., Mi, P. C., and Zhang, Y. H.: Competition of coagulation sink and source rate: New particle formation in the Pearl River Delta of China, Atmos. Environ., 44, 3278-3285, doi:10.1016/j.atmosenv.2010.05.049, 2010. 
Guo, H., Wang, D. W., Cheung, K., Ling, Z. H., Chan, C. K., and Yao, X. H.: Observation of aerosol size distribution and new particle formation at a mountain site in subtropical Hong Kong, Atmos. Chem. Phys., 12, 9923-9939, doi:10.5194/acp-12-99232012, 2012.

Hari, P., Andreae, M. O., Kabat, P., and Kulmala, M.: A comprehensive network of measuring stations to monitor climate change, Boreal Environ. Res., 14, 442-446, 2009.

Hirsikko, A., Laakso, L., Hõrrak, U., Aalto, P. P., Kerminen, V.M., and Kulmala, M.: Annual and size dependent variation of growth rates and ion concentrations in boreal forest, Boreal Environ. Res., 10, 357-369, 2005.

Hirsikko, A., Bergman, T., Laakso, L., Dal Maso, M., Riipinen, I., Hõrrak, U., and Kulmala, M.: Identification and classification of the formation of intermediate ions measured in boreal forest, Atmos. Chem. Phys., 7, 201-210, doi:10.5194/acp-7-201-2007, 2007

Hirsikko, A., Nieminen, T., Gagné, S., Lehtipalo, K., Manninen, H. E., Ehn, M., Hõrrak, U., Kerminen, V.-M., Laakso, L., McMurry, P. H., Mirme, A., Mirme, S., Petäjä, T., Tammet, H., Vakkari, V., Vana, M., and Kulmala, M.: Atmospheric ions and nucleation: a review of observations, Atmos. Chem. Phys., 11, 767798, doi:10.5194/acp-11-767-2011, 2011.

Huang, X. F., Xue, L., Tian, X. D., Shao, W. W., Sun, T. L., Gong, Z. H., Ju, W. W., Jiang, B., Hu, M., and He, L. Y.: Highly time-resolved carbonaceous aerosol characterization in Yangtze River Delta of China: Composition, mixing state and secondary formation, Atmos. Environ., 64, 200-207, doi:10.1016/j.atmosenv.2012.09.059, 2013.

IPCC, 2013: Climate Change 2013: The Physical Science Basis. Contribution of Working Group I to the Fifth Assessment Report of the Intergovernmental Panel on Climate Change, edited by: Stocker, T. F., Qin, D., Plattner, G.-K., Tignor, M., Allen, S. K., Boschung,J., Nauels, A., Xia,Y., Bex, V., and Midgley, P. M., Cambridge University Press, Cambridge, United Kingdom and New York, NY, USA, 1535 pp., 2013.

Kazil, J., Stier, P., Zhang, K., Quaas, J., Kinne, S., O’Donnell, D., Rast, S., Esch, M., Ferrachat, S., Lohmann, U., and Feichter, J.: Aerosol nucleation and its role for clouds and Earth's radiative forcing in the aerosol-climate model ECHAM5-HAM, Atmos. Chem. Phys., 10, 10733-10752, doi:10.5194/acp-1010733-2010, 2010.

Kerminen, V.-M., Anttila, T., Petäjä, T., Laakso, L., Gagné, S., Lehtinen, K. E. J., and Kulmala, M.: Charging state of the atmospheric nucleation mode: implications for separating neutral and ion-induced nucleation, J. Geophys. Res., 112, D21205, doi:10.1029/2007JD008649, 2007.

Kerminen, V.-M., Petäjä, T., Manninen, H. E., Paasonen, P., Nieminen, T., Sipilä, M., Junninen, H., Ehn, M., Gagné, S., Laakso, L., Riipinen, I., Vehkamäki, H., Kurten, T., Ortega, I. K., Dal Maso, M., Brus, D., Hyvärinen, A., Lihavainen, H., Leppä, J., Lehtinen, K. E. J., Mirme, A., Mirme, S., Hõrrak, U., Berndt, T., Stratmann, F., Birmili, W., Wiedensohler, A., Metzger, A., Dommen, J., Baltensperger, U., Kiendler-Scharr, A., Mentel, T. F., Wildt, J., Winkler, P. M., Wagner, P. E., Petzold, A., Minikin, A., Plass-Dülmer, C., Pöschl, U., Laaksonen, A., and Kulmala, M.: Atmospheric nucleation: highlights of the EUCAARI project and future directions, Atmos. Chem. Phys., 10, 10829-10848, doi:10.5194/acp-10-10829-2010, 2010.
Kerminen, V.-M., Paramonov, M., Anttila, T., Riipinen, I., Fountoukis, C., Korhonen, H., Asmi, E., Laakso, L., Lihavainen, H., Swietlicki, E., Svenningsson, B., Asmi, A., Pandis, S. N., Kulmala, M., and Petäjä, T.: Cloud condensation nuclei production associated with atmospheric nucleation: a synthesis based on existing literature and new results, Atmos. Chem. Phys., 12, 12037 12059, doi:10.5194/acp-12-12037-2012, 2012.

Korhonen, H., Sihto, S.-L., Kerminen, V.-M., and Lehtinen, K. E. J.: Evaluation of the accuracy of analysis tools for atmospheric new particle formation, Atmos. Chem. Phys., 11, 3051-3066, doi:10.5194/acp-11-3051-2011, 2011.

Kulmala, M. and Kerminen, V.-M. On the formation and growth of atmospheric nanoparticles, Atmos. Res., 90, 132-150, doi:10.1016/j.atmosres.2008.01.005, 2008.

Kulmala, M., Vehkamäki, H., Petäjä, T., Dal Maso, M., Lauri, A., Kerminen, V.-M., Birmili, W., and McMurry, P. H.: Formation and growth rates of ultrafine atmospheric particles: A review of observations, J. Aerosol Sci., 35, 143-176, doi:10.1016/j.jaerosci.2003.10.003, 2004.

Kulmala, M., Petäjä, T., Nieminen, T., Sipilä, M., Manninen, H. E., Lehtipalo, K., Dal Maso, M., Aalto, P. P., Junninen, H., Paasonen, P., Riipinen, I., Lehtinen, K. E. J., Laaksonen, A., and Kerminen, V.-M.: Measurement of the nucleation of atmospheric aerosol particles, Nat. Protoc., 7, 1651-1667, doi:10.1038/nprot.2012.091, 2012.

Kulmala, M., Kontkanen, J., Junninen, H., Lehtipalo, K., Manninen, H. E., Nieminen, T., Petäjä, T., Sipilä, M., Schobesberger, S., Rantala, P., Franchin, A., Jokinen, T., Järvinen, E., Äijälä, M., Kangasluoma, J., Hakala, J., Aalto, P. P., Paasonen, P., Mikkilä, J., Vanhanen, J., Aalto, J., Hakola, H., Makkonen, U., Ruuskanen, T., Mauldin III, R. L., Duplissy, J., Vehkamäki, H., Bäck, J., Kortelainen, A., Riipinen, I., Kurtén, T., Johnston, M. V., Smith, J. N., Ehn, M., Mentel, T. F., Lehtinen, K. E. J., Laaksonen, A., Kerminen, V.-M., and Worsnop, D. R.: Direct Observations of Atmospheric Aerosol Nucleation, Science, 339, 943 946, doi:10.1126/science.1227385, 2013.

Lehtinen, K. E. J., Dal Maso. M., Kulmala. M., and Kerminen, V.-M.: Estimating nucleation rates from apparent particle formation rates and vice-versa: Revised formulation of the Kerminen-Kulmala equation, J. Aerosol Sci., 988-994, doi:10.1016/j.jaerosci.2007.06.009, 2007.

Leppä, J., Kerminen, V.-M., Laakso, L., Korhonen, H., Lehtinen, K. E. J., Gagne, S., Manninen, H. E., Nieminen, T., and Kulmala, M.: Ion-UHMA: a model for simulating the dynamics of neutral and charged aerosol particles, Boreal Environ. Res., 14, 559-575, 2009.

Liu, S., Hua, M., Wu, Z. J., Wehner, B., Wiedensohler, A., and Cheng, Y. F.: Aerosol number size distribution and new particle formation at a rural/coastal site in Pearl River Delta (PRD) of China, Atmos. Environ., 42, 6275-6283, doi:10.1016/j.atmosenv.2008.01.063, 2008.

Lohmann, U. and Feichter, J.: Global indirect aerosol effects: a review, Atmos. Chem. Phys., 5, 715-737, doi:10.5194/acp-5-7152005, 2005.

Makkonen, R., Asmi, A., Kerminen, V.-M., Boy, M., Arneth, A., Guenther, A., and Kulmala, M.: BVOC-aerosol-climate interactions in the global aerosol-climate model ECHAM5.5-HAM2, Atmos. Chem. Phys., 12, 10077-10096, doi:10.5194/acp-1210077-2012, 2012. 
Manninen, H. E., Nieminen, T., Asmi, E., Gagné, S., Häkkinen, S., Lehtipalo, K., Aalto, P., Vana, M., Mirme, A., Mirme, S., Hõrrak, U., Plass-Dülmer, C., Stange, G., Kiss, G., Hoffer, A., Törõ, N., Moerman, M., Henzing, B., de Leeuw, G., Brinkenberg, M., Kouvarakis, G. N., Bougiatioti, A., Mihalopoulos, N., O'Dowd, C., Ceburnis, D., Arneth, A., Svenningsson, B., Swietlicki, E., Tarozzi, L., Decesari, S., Facchini, M. C., Birmili, W., Sonntag, A., Wiedensohler, A., Boulon, J., Sellegri, K., Laj, P., Gysel, M., Bukowiecki, N., Weingartner, E., Wehrle, G., Laaksonen, A., Hamed, A., Joutsensaari, J., Petäjä, T., Kerminen, V.-M., and Kulmala, M.: EUCAARI ion spectrometer measurements at 12 European sites - analysis of new particle formation events, Atmos. Chem. Phys., 10, 7907-7927, doi:10.5194/acp-10-79072010, 2010.

McMurry, P. H., Fink, M., Sakurai, H., Stolzenburg, M. R., Mauldin, R. L., Smith, J., Eisele, F., Moore, K., Sjostedt, S., Tanner, D., Huey, L. G., Nowak, J. B., Edgerton, E., and Voisin, D.: A criterion for new particle formation in the sulfur-rich Atlanta atmosphere, J. Geophys. Res.-Atmos., 110, D22S02, doi:10.1029/2005JD005901, 2005.

Merikanto, J., Spracklen, D. V., Mann, G. W., Pickering, S. J., and Carslaw, K. S.: Impact of nucleation on global CCN, Atmos. Chem. Phys., 9, 8601-8616, doi:10.5194/acp-9-8601-2009, 2009.

Mikkonen, S., Romakkaniemi, S., Smith, J. N., Korhonen, H., Petäjä, T., Plass-Duelmer, C., Boy, M., McMurry, P. H., Lehtinen, K. E. J., Joutsensaari, J., Hamed, A., Mauldin III, R. L., Birmili, W., Spindler, G., Arnold, F., Kulmala, M., and Laaksonen, A.: A statistical proxy for sulphuric acid concentration, Atmos. Chem. Phys., 11, 11319-11334, doi:10.5194/acp-11-11319-2011, 2011.

Mirme, A., Tamm, A., Mordas, G., Vana, M., Uin, J., Mirme, S., Bernotas, T., Laakso, L., Hirsikko, A., and Kulmala, M.: A widerange multi-channel Air Ion Spectrometer, Boreal Environ. Res., 12, 247-264, 2007.

Mönkkönen, P., Koponen, I. K., Lehtinen, K. E. J., Hämeri, K., Uma, R., and Kulmala, M.: Measurements in a highly polluted Asian mega city: observations of aerosol number size distribution, modal parameters and nucleation events, Atmos. Chem. Phys., 5, 57-66, doi:10.5194/acp-5-57-2005, 2005.

Petäjä, T., Mauldin, III, R. L., Kosciuch, E., McGrath, J., Nieminen, T., Paasonen, P., Boy, M., Adamov, A., Kotiaho, T., and Kulmala, M.: Sulfuric acid and $\mathrm{OH}$ concentrations in a boreal forest site, Atmos. Chem. Phys., 9, 7435-7448, doi:10.5194/acp9-7435-2009, 2009.

Pope, C. A. and Dockery, D. W.: Health effects of fine particulate air pollution: Lines that connect, JAPCA J. Air Waste Ma., 56, 709-742, 2006.

Qian, S., Sakurai, H., and McMurry, P. H.: Characteristics of regional nucleation events in urban St. Louis, Atmos. Environ., 41, 4119-4127, doi:10.1016/j.atmosenv.2007.01.011, 2007.

Ruuskanen, J., Tuch, T., Ten Brink, H., Peters, A., Khystov, A., Mirme, A., Kos, G. P. A., Brunekreef, B., Wichmann, H. E., Buzorius, G., Vallius, M., Kreyling, W. G., and Pekkanen, J.: Concentrations of ultrafine, fine and $\mathrm{PM}_{2.5}$ particles in three European cities, Atmos. Environ., 35, 3729-3738, doi:10.1016/S1352-2310(00)00373-3, 2001.

Salma, I., Borsós, T., Weidinger, T., Aalto, P., Hussein, T., Dal Maso, M., and Kulmala, M.: Production, growth and properties of ultrafine atmospheric aerosol particles in an urban environ- ment, Atmos. Chem. Phys., 11, 1339-1353, doi:10.5194/acp-111339-2011, 2011.

Shen, X. J., Sun, J. Y., Zhang, Y. M., Wehner, B., Nowak, A., Tuch, T., Zhang, X. C., Wang, T. T., Zhou, H. G., Zhang, X. L., Dong, F., Birmili, W., and Wiedensohler, A.: First long-term study of particle number size distributions and new particle formation events of regional aerosol in the North China Plain, Atmos. Chem. Phys., 11, 1565-1580, doi:10.5194/acp-11-15652011, 2011.

Sipilä, M., Berndt, T., Petäjä, T., Brus, D., Vanhanen, J., Stratmann, F., Patokoski, J., Mauldin III, R. L., Hyvärinen, A.P., Lihavainen, H., and Kulmala, M.: The Role of Sulfuric Acid in Atmospheric Nucleation, Science, 327, 1243-1246, doi:10.1126/science.1180315, 2010.

Sogacheva, L., Dal Maso, M., Kerminen, V.-M., and Kulmala, M.: Probability of nucleation events and aerosol particle concentration in different air mass types arriving at Hyytiala southern Finland, based on back trajectories analysis, Boreal Environ. Res., 10, 479-491, 2005.

Stanier, C. O., Khlystov, A. Y., and Pandis, S. N.: Ambient aerosol size distributions and number concentrations measured during the Pittsburgh Air Quality Study (PAQS), Atmos. Environ., 38, 3275-3284, doi:10.1016/j.atmosenv.2004.03.020, 2004.

Wang, Z. B., Hu, M., Yue, D. L., Zheng, J., Zhang, R. Y., Wiedensohler, A., Wu, Z. J., Nieminen, T., and Boy, M.: Evaluation on the role of sulfuric acid in the mechanisms of new particle formation for Beijing case, Atmos. Chem. Phys., 11, 12663-12671, doi:10.5194/acp-11-12663-2011, 2011.

Wichmann, H. E. and Peters, A.: Epidemiological evidence of the effects of ultrafine particle exposure, Philos. T. R. Soc. A, 358, 2751-2769, doi:10.1098/rsta.2000.0682, 2000.

Wiedensohler, A, Chen, Y. F., Nowak, A, Wehner, B., Achtert, P, Berghof, M., Birmili, W., Wu, Z. J., Hu, M., Zhu, T., Takegawa, N., Kita, K., Kondo, Y., Lou, S. R., Hofzumahaus, A, Holland, F, Wahner, A., Gunthe, S. S, Rose, D., Su, H., and Pöschl, U.: Rapid aerosol particle growth and increase of cloud condensation nucleus activity by secondary aerosol formation and condensation: A case study for regional air pollution in northeastern China, J. Geophys. Res., 114, 00G08, doi:10.1029/2008JD010884, 2009.

Woo, K. S., Chen, D. R., Pui, D. Y. H., and McMurry, P. H.: Measurements of Atlanta aerosol size distributions: observations of ultrafine particle events, Aerosol Sci. Tech., 34, 75-87, doi:10.1080/02786820120056, 2001.

Wu, Z. J., Hu, M., Liu, S., Wehner, B., Bauer, S., Maßling, A., Wiedensohler, A., Petäjä, T., Dal Maso, M., and Kulmala, M.: New particle formation in Beijing, China: Statistical analysis of a 1-year data set, J. Geophys. Res., 112, D09209, doi:10.1029/2006JD007406, 2007.

Xu, P. J., Wang, W. X., Yang, L. X., Zhang, Q. Z., Gao, R., Wang, X. F., Nie, W., and Gao, X. M.: Aerosol size distributions in urban Jinan: Seasonal characteristics and variations between weekdays and weekends in a heavily polluted atmosphere, Environ. Monit. Assess., 179, 443-456, doi:10.1007/s10661-010-1747-2, 2011.

Yao, X. H., Choi, M. Y., Lau, N. T., Lau, A. P. S., Chan, C. K., and Fang, M.: Growth and Shrinkage of New Particles in the Atmosphere in Hong Kong, Aerosol Sci. Tech., 44, 639-650, doi:10.1080/02786826.2010.482576, 2010.

Yu, F. and Luo, G.: Simulation of particle size distribution with a global aerosol model: contribution of nucleation to aerosol 
and CCN number concentrations, Atmos. Chem. Phys., 9, 76917710, doi:10.5194/acp-9-7691-2009, 2009.

Yue, D. L., Hu, M., Zhang, R. Y., Wang, Z. B., Zheng, J., Wu, Z. J., Wiedensohler, A., He, L. Y., Huang, X. F., and Zhu, T.: The roles of sulfuric acid in new particle formation and growth in the mega-city of Beijing, Atmos. Chem. Phys., 10, 4953-4960, doi:10.5194/acp-10-4953-2010, 2010.
Yue, D. L., Hua, M., Zhang, R. Y., Wu, Z. J., Su, H., Wang, Z. B., Peng, J. F., He, L. Y., Huang, X. F., Gong, Y. G., and Wiedensohler, A.: Potential contribution of new particle formation to cloud condensation nuclei in Beijing, Atmos. Environ., 45, 6070-6077, doi:10.1016/j.atmosenv.2011.07.037, 2011.

Zhang, Y. M., Zhang, X. Y., Sun, J. Y., Lin, W. L., Gong, S. L., Shen, X. J., and Yang, S.: Characterization of new particle and secondary aerosol formation during summertime in Beijing, China, Tellus, 63, 382-394, doi:10.1111/j.16000889.2011.00533.x, 2011. 